\title{
Adjourned Discussion. Thursday Evening, May 2, 1867
}

\section{Captain R. N. Fishbourne in the Chair}

To cite this article: Captain R. N. Fishbourne in the Chair (1867) Adjourned Discussion.

Thursday Evening, May 2, 1867, Royal United Services Institution. Journal, 11:46, 462-484, DOI:

$10.1080 / 03071846709417313$

To link to this article: http://dx.doi.org/10.1080/03071846709417313

册 Published online: 11 Sep 2009.

Submit your article to this journal $₫$

Џll Article views: 3

Q View related articles $๘$ 
out our faults are, after all, our best friends. I hare always been and alwags shall be most anxious to co-operate with Captain Coles; and I think I am not an insubordinate officer of the Admiralty. I shall be only too proud to act under authority in endearouring to bring this question to a proper bearing. I will only further Eay that Captain Coles rery early in his paper used a remark which I object to. Ho spohe about the persons in office who resist the speedy adoption of his principles as the "anti-turret party." Nor do pras xemember that the late Adniralty did not inrent brondside ships. Broadside ships hare existed for ages. Captain Coles is the innorator, and it is the duty of the innorator to shom that the old system is bad. Ho comes forrard with a new inrention, and because those in offico hare not so much confidence in it as he has himself, he calls them a "party." This, I think, is absurd. It is the too ardent adrocates of turrets who form a "party," and they, not we, are partizans.

The discussion was then adjoumed till the following erening at cight o'clock.

\section{Adjouraco Discussiox.}

\section{Thursday Erening, May 2, 1867.}

\section{C.JPAIs FISHBOURNE, R.N., in the Chair.}

The Curnarsx: I hare no doubt jou will think it desirable to confino the dis. cussion as much as possible to the points raised in the paper, and I therefore proposo that Captain Coles should read us the conclusions that he has comc to.

Captain Corres read the following conclusions :-

"In conclusion, it is obrious, I bclicre, that by lowering the frecboard to the minimum, the following adrantages are obtained, riz.:-

"Ist. A steadier gun platform, and incidentally less risk of bcing struck below plating whilst rolling in a scawny, as well as the power of fighting thesc heary guns in a scarray.

"2nd. Diminution of area to be plated nnkes smaller ressels and thiclier plates practically arailable.

"3rd. Diminution of target and increased thickness of plates, both incident to lowring the free board, secm the only cffectual means of resisting the adranees of modern guns and projectiles.

"4th. Iess cxpenzo in the first outlay to produce these costly ships, since less tomnage is required, and fewer men, making it practicable to man more ships in time of wir.

"The disadrantages often alleged to be incidental to a low free board, riz., discomfort to the ship's company, is obriated in ressels of erery class by meaus of a hurricanc deck, such as I hare described in figs. $6,7,8$, and 9 . I rould also obserre that the recent improrements in guns and projectiles lare inereased the risk, preriously very great to ressels with high frce board and central casemated batteries, from the entering of the shell, either through their large ports, or through their weak eiles, and this is a risk which there is no means of obriating in brosdside ships.

"Disirgarding for the moment all other considerations than the comfort of the ship's conpany, it still scems questionable whether any increased comfort in time of peace from a ligh frec board, is not moro than counter-balanced by their greatly increesed weakness from the canse I hare mentioned, in timo of war.",

Captain Scorr, R.N.: Mr. Chairman and Gentlemen, the lecture we have had is so important, that $I$ think it necessary to follow the principal points seriatim, bcing as brief as possible on ench; and; with that view, I will first remark that we all of course spcak of what we are full of: "Out of the fulness of the heart the mouth speaketh." So Captain Coles speaks of his proposed turret-ships, and cxhibits, as jou see, cight 
or nine kpecimens. There is the "Captain," now building. But we must remember that the rapidity of improrement is rery great indecd, aud therefore the comparison between ships building with those not only built, but also in commission, is manifestly unfair. For a fair comparison wo must compare cach idea of the turret ship at a particular time with the broadside ship of the eame tine, or clse we do not get the true comparison. The broadside ships are being dereloped day by day quite as much as the turret-ships are being dereloped. I think $I$ shall be able to aloor that the whole principle of the broadside ships has been considerably improred. We must not be tied down to that comparison which, if Captain Coles will allow me to sey so, he has so constantly made with broadside ships, and now makes of the "Achilles," a ressel built years since, and armed with 68-pounders, againet turcet ships armed with the heary guns that are now carried. When these broadside ressels were desigaed, there was no such gun, therefore they could not be designed for what did not exist. In order to have a fair judgment on the subject, it is necessary to bear all these points clearly in mind. Fow, of the Channel squadron the reports are seemingly unfarourable. Fou heard them read laet night; the most unfarourable parts of them were read, but why were they unfarourable? because the guns were mounted on the obsolcte plans of 1864 and 1865 . We had gone into a new system of artillery, but we had stuck to our old carriages, tinkered up, it being probably thought they would bo cheap, which they wore, and rory bad at the same time. Now, to show that this rick is fully borne out, $I$ haro to revert to the opinions of the different Offcers, and without saying that they are rerbatin, I, as one of those who commanded a ressel during this time, and knowing well what passed in the ressels, hearing the opinion of cach Captain, can gire a tolerably clear idea-at any rate, I ought to be able to give jou a clear idea-of their opinions. Now I find that the Captain of the "Hector" reports that the compressors wero not to be depended upon, and that the train mhips carried amay, the compressor should hold the gun on recoil, and the train whip should run the gun in; so that the tro principal things for working the guns were not to be depended on. The Captain of the "Achilles" also says the compressors were unreliable. The Captain of the "Irord Clyde" says that the ranning in and out gear is bad; there mas no control orce the guns. The Captain of the "Pallas" wishes pauls fitted to prerent the guns getting adrift. And as to the "Research," I hare no hesitation in stating that her guns did get adrift, and I showed the reason. Can it be surprising that with the fittings I hare just mentioned, those old fittings, and with such a tremendous swell as there vis running at the time of the special trinl, that the guns could not be fought satisfactorily? When has it erer been attempted to fire gans under similar circum. stances? It must be remembered that the Admiral expressly states in his report that none of our wooden frigates would hare thought of opening their ports in such weather; and here rere those resscls laid purposels broadside to the swell, and attempts mado to fire the guns with the old fittings, and therefore the result nas not satisfactory. The explanation is as simple as possible. But to compare this weather, when the men conld scarcely stand, with the weather in which the "Royal Sorereign" guns were tested, is absurd. She ras merely tested in the Channcl ; and here were those broadside ressels rolling about in the rers worst swell that could be found in the Atlantic. Now as to tho "Dellerophon's" firing only two rounde, which hare been rery much dmelt upon, the "Belleroplon" went to sea before her gun carriages were ready. She had two guns on board; one of them was mounted on Armstrong's competitire carriage, which had competed with nine, and fired some sisty rounds; and the other was mounted on a wooden carriage, so weak that, after one or two rounds before the ship went ont, they decided that it ras unsafe to fire it any more; so that gun could not be fired. In the other case of the gun, its car. riage had been taken out and restored, and then no person could adjuat Amatrong's compressor. At the first round fired, the gun came in flying. The compreseor was screwed up again, and the samo thing happencd. Fobody could adjust it, or perhaps from the effects of the competition its holding powers were gone: Whaterer was the resson, the second time of its acting in that riolent way, there being no power to control it, the Captain wisely determined not to fre again, but he sajs expressiy he conld hare rery casily fought his guns eren at that time. I am sorry the Captain's 
reports are not printed, because he so decidedly says this. Now mhen, as I hare shown, the Admiral speabs of guns badly mounted, it was what zcas, not what is at the present time. What usas is simply this, that the ports were obliged to be opened to load the guns; what is, that we can lower our ports down in a sca-was, and load through the scuttles, and, with the training gear that is to be applied, this will be effected very casily, and theso guns will be fired with great mapidity, far quicker than any firing in the turret, as I shall presently show. So that you sce what Captain Coles so much insists upon, as to the powder being kept drs, is actually being carried out. The port is closed, there is simply a scuttle. Then, with the new fittings, the guns are run out rapidly. There will be no difliculty in training the guns, and elerating as they go out, and thus the guns can be hept bearing upon the object. The eaptain of the gun las plenty of space, and is enabled to see, and he fires when the gun is upon the object. Now, with reference to the size of ports: in the "MIinotaur ${ }^{31}$ the port was flled up, so that it was only 2 feet 9 inches deep, and 2 feet wide, and the gun then trained 30 degrees each way. There was no difteculty at all found in pointing, and tho practice was excedingly satisfactory. With the " Dellerophon" the lower part of the port was elosed up, and narromed to 2 feet 1 inch, and the gun trained $3 \frac{1}{2}$ degrces each way. This carriage is on board at the present time. Some Offecrs probably have seen it; at any rate they will be enabled to sec it, if they wish. There is another reason mhy, as I said before, the ports can be closed up, as all that jou want is sufficient height of gun to fire over the lower port cill you can use au clerating and depressing carriage. I shall presently show the adrantage that it would gire the broadside-ship, and then the gun goes closer out in the broadside than in the turret. There you sce a diagram of the tiurret. I am not able to bring it in front, but jou will at once see that in the turiet the gun rould be further out. Therefore for the same sized part, you mould get less eleration and depression in the turret than jou do with the broadside; and the turret's port will be found a very little smaller than tho port was in the "Mlinotaur" when it ras closed up in the manner I speas of. As to the gun's recoil, which Captain Coles thought to be limited to coming in six inches, I mas inform lim.

Captain Corrs : I did not say coming in six inches. I said sir inches inside the port. Captain Scots : In the "Irinotaur" the gun was allowed to come in $\mathbf{3}$ feet $\mathbf{G}$ inches. It camo in 3 feet 6 inches clear of the side. That was found a great deal more than was necessary, so the gun on that carriage is now not allowed to come in more than 18 inches, clear of the port; and that gires a mean of about $a$ foot, and there is not the slightest difficulty in londing. $N o w, a s$ to sceing all round in the turret when that figure gets up and looks round, and secs a ship, it cannot bo supposed, for one instant, that jou ere to depend on him, that is, on the captain of the gun for picking out his ship and firing at it. Why, in a general action, you would have one captain of a gun firing at a fricndly ressel, and another captain firing at the cnemy. It must bo under the direction of the Omeer of the quarters, who must be told in general terms whero the resscls are, and to look out for those resscls. In fact, if a seaman exercises his indiridual ideas on the subject, you will hare the greatest possible confusion. Therefore I think that remark as to tho adrantage of the captain of the turet gun, getting up and looking round, is really an imaginary adrantage. I belicro that the "Captain's" port, or the gun in the "Captain" is $11 \frac{1}{2}$ fect out of the water. Am I right?

Captoin Cores : Ies.

Captain Scort: Tery well, the gun in the "Ifonarch" is to bo 17 feet out of the rater-tliat ressel which is so much objected to. Now, in Admiral Yelrerton's report, at page 7, ho states, "The turret-system of arming a ship " would hare a great triumph on this occusion, for there is no doubt that a "sea-going turret-ship, say 12 or 14 feet out of tho rsater, would hare fought " her guns without the slightest difficulty, and hare fired easily six shot to erery one "from our broadside-ships. I do not here allude to the "WJrem,' for the sen would " hare xashed into the ports of her turrets and smamped crerything inside." Tho Admiral here expressly points out that it is a resscl with high frecboard-a resscl whose gun would be 17 feet out of the water, which is precisely what the "Monarelh's" is, that would hare had an adrantage orer his squadrou. 
Tho Crarryax : I do not think it is so stated there. It says " the gun."

Captain Scorr : It does not say "the gun." It snys, "a sca-going turret-ship", say 12 or 14 feet out of the wator."

The Cinnmiss: Read the whole of it.

Captain Scorr: "There is no doubt that a sca-going turret-ship, say 12 ov " 14 fect out of tho water, would hare fought her guns without the slightest "difficulty, and here fircd easily sir shot to erers one from our broadside. "ships. I do not here alludo to the 'Tyrern, for tlic sea would hare traslied into "the ports of her turrets and smamped erergthing inside." But the sea in the same manner will roll orer the "Captain's." deck with a low freeboard, and, to use the words of the Admiral, "swamp erers thing inside her turrets." The rery incline of her deck will tend-will materially assist this action. Look at a brenkwater, and sce how the sea rolls orer it; but on dropping the port, as rou can in brondside-ships, and londing through the seuttle, the whole weight of the sea may come firing against the port, but it cannot sweep orer the deck and swamp ererything inside. I turn again to the Admiral's report-to pages 2 and 5 , to see tho ralue of the ressel with the low frecboard. "On both these occaeions I was able to "judge of the performance of the squadron, blowing hard with a heary sea, aud " hare no hesitation in saying, that under all the circumstances of bad weather in "the Atlantic, I see no reasou to apprehend that the ships of this squadron would " make morse reather of it than any of our line-of bettle ships. I must, howerer, "make two exceptions to this, namely, tho 'Hector' and 'Wifern,' neither of "which are, in my opinion, in their present condition safo in bed weather; the " 'Hector,' from the difficulty (if not impossibility) of getting rid of the wnter she " would be certain to ship, if caught in a cross sea caused by a sudden shift of wind; " and the 'Wircrn', from being so low in the water, that with the evergdas $\Delta$ tlantic "swell only, she is compelled to be battened down, if not head on to it, and eren "then the sea breaks orer her deck in a way that renders it a service of danger for "tho men to pass along it. On reaching tho cruizing-ground she was soon short of "coal, and I nas obliged to sead her to Bantry to fill up; but the experience I had " of her performance up to that time convinced me of her unfitness to lecp the sca, " and I ordered lier to remain at Bantry until the end of the cruiee, when she joined " me haring to put back on ono occasion in the face of a strong sotith-caster. I was "subscquently informed by Captain Burgoyne, that on the occakion of steaming down "Channel, this ressel had tro of her fires partly extinguished through shipping a " heary sea, which circumstance hos already been reported to their Lordships. The "' "Wyrern' does little under sail, and is totally unfit for the dutics of a sca-going "ressel, but she is well adapted for coast defence." Fow, I was one of those present who Ear the "Wyrern's" pitching and rolling, and certainly she did it to a rery considerable extent. She had netting triced up on each side, and on one occasion a heary sea rolled on board of her, and when it left, the men were caught in one of the nettings, like fish, safely bagged and brought back. dgain the helmsmen could not pass along tho deck without a wetting in ordinary weather. As to tho "VJrern," tho Admiral further says, "This ressel could nerer hare been intended as a cruizing or sea"going ship, for, although sho is buogant and rises to the sea, jet from her being so "s rery low in the wuter, it rushes up her sides orer all, and when broadside to the sca, " it is impossible to more about on her decks without the risk of being washed orer" board. At sea she is almost almajs battened domn, to the exclusion of air in the "enginc-room and stoke-hole. Under sail she does rers little, asd her stownge of " coal is limited." I will make one remark with respect to her stowage of coalCaptain Burgosne filled up, being ordered to rejoin the squadron the last time, he did not consider it eafe to take in the whols quantity of coal, and therefore took conaiderably short of the quantity. The report continues: "If the' Wyrern' had to cross the "Atlantic, I would suggest that she be fitted with a forc and aft bridge, like the " 'Mriantonomoh', and, like that ressel, be escorted bJ a powerful steamer." Now, if the "W Trern" was not built to cross the dtlantic, and operate along a storrs, coast, for what on carth was she built? Next with regard to sail powor, so necesenxy in cruizing. As you sce Captain Coles' imaginary ressels, because I must call thom so, are to hare little or none. I suppose I make no mistake, however, in sajing that 
those are sails (pointing to diagrams). They cannot be the sails of a boat hoisted in the centre of the ship. I see they are the ship's sails, but on the hurricane-deck shown, would there be room to work a ressel's sails properly? I ask any one to look at the amount of room on that hurricane-deck to work a ressel under sail.

Captain Colez : 24 fect broad.

Captain SCorr: As respects the valuc of sail power, I may mention that the "Re. scarch" was ordered to rejoin the squadron. Of course the "Rescarch" had rery small stcam-power, and so the squadron steamed array and left me behind. I could not help myself. But being ordered to rejoin, and steaming out of Cork, just as I got abreast of Daunt's rock the ressel broke down. In the erening, the Admiral had said to me, the weather was so bad, and there was such a masty sea on, he thought I had better not go, but if, in the morning, I was still auxious to leare, I might go, so I went. There was a rery nasty sca, a tum. bling sea, close to Daunt's Rock. Wo were making a close share of it, for we could not afford to burn much conl. I thought it possible that the "Research's" passage would be timed, and immediately made sail. We wore at once sharp round close to the rock and stood orer across to the other side and worked out under sail against tho breze and against the tide. There we were beating to windward some hours, until the Engineers repaired the ralve, which had broken, and then we went on again, steaming and sailing. Now there is a case, in which, if the ressel had not liad sailing power, I do not know what she could hare done. We could not hare anchored off Jaunt's Rock. We must have gone ashore there. Next is to the accommodation of the turrets, I rill turn to page 169, in the Housc of Commons Return on Turret. ships, and read to you what is said, because there is nothing like what is oflicinl as to matters of fact: "The space occupicd by the turrets and the absence of "gun decks, renders it difficult, if not impossible, to protide properly for the " accommodation of officers and ship's company; while the necessary clcarness of "the upper deck prerents her from carrying the requisite proportion of boats, "spare spars, and other gear, which must erer form a necessary part of the " cquipment of a man-of-mar."

Captain Cores : What report is this?

Captain Scorr: That is what Admiral Key gires as a summary, and places in the luands of Gorernment as an official document summing up all those points.

Sir Frederice Nicnossox: It is the Report of the Earl of Lauderdale's Committec.

Captain Scorr: Yes, the Earl of Lauderdale's Committec, I hare read from the paper, because I wish to go point by point through it. The turrets are deficient in offensire power, because thes are too lor to firc dom upon torpedoes which will be largely employed, I doubt not, in future warfare. You sce the deek of tho turret ship is also in the way. The amount of depression the turret guns are calculated to gire is only 5 degrees, and from this small amount of depression, and being so low in the water, they lose the raluable point of being able to fire down not only through a torpedo; but through any other ressel alongside of them. The decks of ressels, up to the present time, are not armourcd, therefore, I think, the height of the gum is a rery great adrantage in enabling jou to fire down on a ressel that may be alongside. Sccondly, the turrets fire rery slowly, because space is limited. If you look at that diagram, you will see at once what a small amount of sprec there is for loading. These (pointing) are tro 600-pounders, I beliere the turret is the size of that which is to be in the "Captain;" and the gencral arrangements are the same.

Captain Coles: What is the diameter of that turret-the interior dianeter?

A Mejmer : It is probably 25 feet.

Captain Scorr : It is in proportioin to tho size of the gun. I will tell jou what it is taken from. I succeded some time ago in getting a sketeh of the turret derised by you at the end of 1865 for tro 600 -pounders, it was sent up to the 1 dmiralty. This is the exact copy of it.

Captain Cones : That is not the "Captain's."

Captain SCOTT: It is rery similar to it?

Captain Coles : No.

Captain Scotr: If you sas it is a foot lnrger or smaller, $I$ will take it at that. 
Captain Cores: It makes a difference in the diogram.

Captain Scorr : But for all practical purposes, as to epace, it is the aame?

Captain Cores: That will make all the practical difference in the illustration.

Captain ScorT : I shall bo happy to allow you the benefit of a foot or tro either way, if jou will point out where it is wrong; but, as you can see, the space is excecdingly limited, owing to tho roundness of the turret. This platform is very nearly 4 feet high. The man has to get on it in order to load, so that paesing up the shot and powder, especially when the ship is rolling, with the sea coming in, would be a serrice of no slight difficulty. The man cannot stand upon the deck, as in the broadside, and he has not room to lond; therefore, you will find inrariably, the firing of the turret gun exceedingly slow. Actual turret warfare confirms this; and the firing of the "Rojal Sorcreign" has ghown exactly the same result. Now, as to Captain Coles' Report on the quickness of firing, in the Trusty's Turret, there is a rery simple solution to that. The gun was only a 40-pounder, and in the turret, was mounted on an inclined plane, so that when fired it run ont again, and as it was a breech-loader, it could be loaded at once; whereas the gun mounted on the broadside had to be rum out by the crew. That made the difference, and in that lies the difference in the times of firing. Whether Captain Poxell made the mistake I cannot tell, but that is the rcal reason of the difference in the quickness of firing in the Trusty: We will turn to page 168. Here are all the experiments with the "Roval Sorercign's" firing. It is only necessary to giro them generally.

Captain Cores: Will you state the jear it took place?

Captain Scorr: The 3rd of October, 1865, is the date of this report.

Captain Cores: This is 1867.

Captain Scotr: I will gire you also the firing of broadside guns in 1865, and then put the tro side by eide, year by jear. With the one-gun turret, (we wont go to the two,) there was an interval of one minute and trenty-three seconds between the firing the ronnds, and this was the quickest number of rounds that wore fired. What Admiral Key says is this :- "In the "Roral Sovereign" a gun's crew of 30 "men who had been carcfully trained in a turret for nearly a year, and who had "fired about 100 rounds with shot, beside much practise without firing, completed "ten rounds as follows, the quickest ten consecutire ronuds being selected, ride "Report B." And these are tho quickest ten consecutive rounds that were fired. They occupied 13 minutes and 51 seconds. The gun carringe that was put on the "Minotane" was completed in 1865; but the experiments did not take place until January, 1866, as there were no competitors ready. Sir William Armstrong was to hare come forward as a competitor, but did not. One of the Arsenal carriages did howerer turn up. That gun carriage had only four men at it, who had been at the "Research's" iron gun-carriage before, the others were taken from volunteers. The whole crew of the slip roluntered to go. The gun's crew was 14 men, not 30, as in the turret. The firs time they fell in, the gun was fired ten rounds in eight minutes and fifty-four seconds.

Sir Frederick NichoLsox: At a target?

Captain Scotr: No; under just the same circumstances as the others. We are taking the quichest ten rounds. The crew pointed every time and tumed the gun.

Captain Cores: In this casc, with those tro guns a small target was fired at 1,000 yards distance, and good practice made. That is rery different to firing at notbing. That is child's play. Any one can fire a gun off.

Captain SCOTT: But as to the very quickest interval between the rounds-there has been no shorter interral on board the "Royal Sorcreign" than one mimute in all the firing there. In the "Minotaur" following up this first quick firing, the later rounds wero only with half-minuto interrals. Ten rounds were fired in four minutes and forty-eight seconds. Another ten rounds in fire minutes and one second. Now you will sce what it really comes to, as to quicknese of firing. In the "Bellerophon" the other" day with elongated shot which are crceedingly difficult to load, not the round shot, which were tried in the turret, but with elongated shot weighing $260 \mathrm{lb}$, iustead of the $150 \mathrm{lb}$., round ball, fire rounds were fread in three minutes and forty-one scconds. With respect to the rolling, I need not touch upon that, because the "Wyrern" rolled quite as much or more than the "Resemeh," and

roL. xI. 
in the recorded rolling you will find that the "Wyrem" rolled as much as any ressel in the squadron. As to the farour shown; I jare understood that $£ 13,000$ was spent on the "Scorpion." The outlay on the "Rescarch," has been $£ 11,000$, including putting a deck on her, and making her in fact a rery different ressel, and a very comfortable one. This is altogether from first to last, on her fitting 3 and on her alterations, and erergthing that was done. She has been very considerably more than three years constantly employed baekwards and forwards. The "Royal Sorereign" has been continually in hand, and $I$ beliere she has been in hand for the last six months.

But let us now examine the relative power of the Broadside and Turret ressel, and suppose the case of tro enemies engaging the "Bellerophon," and two engaging the "Captain"-in one case we hare a broadside in the "Bellerophon," of 1,500 lbs., and in the case of the "Captain," of about 1,200 lbs against each enemy. If you tabe the quickness of firing to be inrersely as the size of the guns, that of the 600 -pounders would be rery slorr, and I should say the weight of metal discharged ngainst two enemies by the "Belleroplion " from her being able to discharge on both sides together would be treble, certainly more than double, that of the "Captain." The "Momarch" I saw a fer days ago, and I am happy to state I did not see that she was being turned into a box. As the scmi-turret has becn spoken of, I may state that tho guns are put out here, the after gun fires right a-beam and right aft, and the forward gun right a-beam, and also right forwarl, so that these two guns can fire right $a-b e a m$, and command a-head and n-stern. Theso two guns are a rery great height out of the water. 'They are orer 20 fect. I do not think that that is a semi-turret: it is a fixed thing. Of course wo gire Captain Coles all credit for the acloption of the turn table which is a very great adrantage, the distinetire feature bcing a turn-table which carrics the gun upon it, enclosed in su arnour casing. I may here say a word or two about one's own particular ranity, but first I wish to show that the turret has been well considered and well dereloped, I think Captain Coles has lad great adrantage in that respect. He has been working at it continuously, and his suggestions as to mounting the guns, snd on almost all points, larro been carried out, which has not been the case with the broadside ressels.

Captain Cons : MIay I ask how you know that?

Captain Scorr: As far as I see, and as far es what you hare done, I beliere it is pretty nearly the fact. For fast cruisers I have been inclined to gire up armour altogetler, and to get great licight of frec-board out of the water, trusting to the power of the guns to keep down in a great measuro the attack of any rival ressel. I consider that we could not go far wrong in building fast unarmoured ressels; and therefore as one derelopment of the broadside, I lare taken a small turu-table, and having 12-ton guns upon each side, lare used it so as to gain the power of firing a-hend or a-stem ; (all those three guns will fire within 13 degrees of the line of the keel forward or aft). My idca is to fire with great rupiclity, which sou can do on the broadside, and within 13 desrees of the line of the beel. Tou may diselarge your three guns, jou may shear your ressel only through 26 degrees, and then you may dischinge sour other guns; nnd you get a great leight out of the water. This sea here is shown excedingly small, (pointing) but the Atlantic ware is about 12 feet in height, and would continually interpose between the turret gun and the brondside ressel.

Captain CoLes : The turiet gun is 12 fect in height, the same heiglit as the broalside. MIy principle is the same height in ships of the same class.

Captain Scort : I am alluding to the "Captain." The gun is low: it certainly is not ligh. If the gum is high it does not represent the "Captain." That scens to be a high frecboard and a high gun, and it does not carry ont the principle of the low freeboard.

Captain CoLes : Oh jes, it does.

Captain Scorr : Certainly it does not illustrate the "Captain." I hare made a few remarks on this subject. It is onc that needs rery great consideration, and I belierc that these discussions hare a rery good effect, for we are shown our weak points, which we cannot sec before. We are all too fond of our own plans; and in laying them before you of course we get them fully diseussed; and in fiet, the whent 
is sifted from the chaff, which I hope will bo the case at the present time, and that all of us, working together as wo are cloing, mas assist-bceause tlat must be the ultinate object of us all-in placing our country in snch a position that she shall remain the unriralled mistress of the seas.

Vice-Admiral R: S. Ronissos, Controller of the Nary: Mr. Claiman: It is with extreme diffdence that I renture toaddress theandience that I now see before me, for sereral reasons. I bnow that the subject on which I am about to speak is one with which most people here are not only thoroughly acquainted but on which they would delirer their opinionsin far better language, and in a far clearer stfle than I can possibly attempt to do. In the rext placo I hare not had the adrantage of hearing the commencement of this lecture, or hearing what the gallant offecr Captain Coles has, I hare no doubt, so well and so ably put before the meeting, and 1 an therefore rather in the dark as to the points on which I msh to direct my obserrations. But this to me is perfectly clear: we are discussing a question of the rery greatest moment, a question on which all personalitics should entirely disappear. Howorer amueing it may $b c$, and how: erer adrantagcous for the moment it may be, in discuesing such questions as these, to make uso of a personal argument, or to gire a home-thrust to an opponent, the cause of truth-that cause which we know is at the bottom of every man's desire in this asscmbly - the cause of truth suffers in the end from the temporary triumple anybody may obtain by a good hit and a smart thrust. Fow I wish as much as I possibly can, in discussing the question which I wish to discuss, to aroid personalities. If in adrocating the riews I hare to adrocate, I am unfortunately led to mention anjbody's name, I trust that I shall mention it in such a way as to gire no cause of offence to that person, and should I by any accident make use of an expression in the fearless and frec discussion which I court for $m y$ orn opinions, and which I think that others will be equally willing to accord to me the liberty of using-I say, if by any accident, any word or phrase of mine shall hurt any such person's feelings, I apologise beforehand, and request him to attribute it only to my unskilful use of the reapons I wish to usc, and not to any desire to be disagrecable to him. I should also ajologise, before going much further into this subject, for one point which you will rery soon find out. IIy occupations and my arocations day by day are so laborious, that I stand before you not a strong man, not a person capable of making much exertion, and in general, at this time of the day, so completely orerwhelmed by the labours that $I$ hare to undergo, as to be little fit to address an audience. Now, Sir, the subject which we hare to discuss, which I wish to do with as much philosophy and knowledge as I am ablo to bring upon it, is " tho turret sjstem versws the broadside system," and I wish to diseuss that subject rationally r.nd logically. To do so, we must hare a clear understanding of what is meant by a turret-slip, and what is meant by a broadside-ship. Now I stand before you-and perhaps some of - you who hare found out that $I$ am the Controller of the Nary may be surprised when I say that I stand before you the oldest, the most consistent, and the most persistent adrocate of the turret system-yes, of the turret sjstem, for that which it is capable of doing; not of a system which is incapable of performing the rork re want it to perform, but the adrocato of that system which can perform it, and which can perform it better than any other. Quite in the early dajs when Captain Coles commeneed his most meritorious labours-labours for which I give him all possible credit,-I met my friend Captain Coles-if at this day I may call him my friend-I met with my friend Captain Coles in a state of extreme dificulty, having got his system, the excellence of which was erident to me, before a certain department of State which I will not nane, and haring got himeelf into extreme trouble and difficulty with that department. IIc was bind enough to take me into his model shop, and to show me the invention, which with so much shill and talent he had prepared for that department, and he also sliowed me some correspondence, which prored that they were very great diffeulties in his way. I am happy to say I was the means of remoring those difficultics. I am also happy to say some time after thit, I became Controller of the Nary, and was able to forward the riens then entertained by Captain Coles, of the turret system. I only state this much to show why I eay that I was one of the oldest adrocates of the turret system. I may say, without speaking too much of myself, that I assisted Captain Coles extremely 
to get the first turret that crer was fried, brought not only to the notice of the Adminalty, but tried in a ship under fire. I assisted Captain Colcs moreorer to get the first turret-ship that ever ras designed or laid down, namely the "Prince Albert." Now I do not want to say nore upon mf persistency or consistency in adrocating the turret system, for what it is fit, and not for what it is not fit. I hare persistently and consistently, and do at this moment contend that the turret system, as applied for purposes of cither coast defence, inland narigation, or siege artillery, to attack an enemy's port or rondstend in inland waters and in fine weather, is the system of all others in which you can combine the greatest amount of offence and defence. I have nerer deriated from that opinion, publicly or prirately. I adrocated it eight Jears ago. I adrocate it now; but because I adrocate for a particular purpose a particular weapon, I am not, I think, bound, either logically or philosophicnlly, to say that this weapon, which I beliere and know to be the best weapon for that particular purpose, is an equally cflicient reapon for all other purposes. I know well, for instauce, what you can do with an axe. I hnow, I hare seen work well done by barbarians, if I maj so call the Chinese-with an axe, but no one would tell me an are is able to do all that a saw is able to to. And so while I say, and say with a certain knowledge and clear conriction of tho fact, that a turet ship for const defence and for the purposes I hare named, is the rery best weapon you can uze, I use my judgment, and I hare within myself as clear a conviction, founded upon argument, refection, and logic, that this may not be the best ressel for sea-going and cruising purposes; and to explain more fully what reason I have for this assertion, I mould like this Meeting to consider for a moment with me what is the very best form you can give a turret-ship for the purpose of hostilities in iuland waters, whether for offence or defence. In inland waters you are restrained by nono of the difieulties which the ocean puts into contact with fou. You hare simply to know how much reight you intend to carry upon the ressel, and to proportion your carrying power to the weight that you intend to put. The lower, therefore, any such ressel can be construeted, the better; the less the draught of water steh ressel can be constructed with, the better; all that yon require in such a case is a ressel so strong in crery part thit no shot shall be able to penetrate it, except under circumstances which ire must gire up, because we cannot absolutely orercome the power of artillery; but under ordinary circumstances rou can construet, for the purposes of coast defence, or, as I hare said, for siege artillery, without the smallest difficulty in the world, a ressel low in the water, costed with armour-plating, and carrying the heariest possible guns, and this you may do comparatively in small dimensions. Now when the idea dawnel across the gallant offeer, it was a great idea; the idea darned across hin to put a gun upon a turn-table, and to surround that turn-table with armourplating; he came positively upon a rery great inrention-a tery great and successful idea came across his brain. He has laboured in rarious directions with assiduity erer since, but the first thought, and the first realization of that thought, must hare been to him a rery considerable and great satisfaction. It is that thought, that iden, embodied in a lor lerel armour-plated ressel like what is now knomn as the "Monitor" ressel, which is the most perfect conception to my mind of what jou ought to hare for attack and defence of ports and arsenals, and if the gallant offeer had stopped there, I should hare said he had done grite enough for his fame-quite enough for the beaeft of his country and for the benefit of the world. IIe has, howerer, (and he is perfectly right-lie views the thing in a different light to what $I$ do-his reflections upon the subject hare brought him to $a$ different conclusion from the one I hare come to) - he has conceired that there was no more difficults in adapting this system of turret-ships-that is to say, carrying a rerolring gan on a turn-table, surrounded by an armour-plated shield-there is no more difficulty in carrying that in a ressel to contend with the wares of the Atlantic or the stormy ocean, it would hare to cross, in conjumction with rery great speed, than in making the "Mouitor," or the const defence ressel to mhich I hare just referred. Fow it would not be difficult to show that that cannot be; it would not be difficult to show that howerer excellent the system mhich requires lowness, for instance, of frecboard, (it is a rital point in a "Monitor" that pou should not 
expose any of her;) it is not diflicult, I think, to show that although that requisition may not be incompatible with a perfect coast-defence ressel, or with a perfect piece of siege artillery, jet that the requirements of a sea.going ship, are entirely different, for the moment you get into wares and into sea-way, the lowness of freeboard signifies at once, that your gun canmot be high out of the water; if your gun is not high out of the water, there come betwecn you and your object rarious wares more or less high, and your artillery is paralysed. For instance, if your gun is only fire feet out of the rater-take that as an illustration-these figures will illustrate it better than austhing else-say that jour gun is only fire feet out of the water, and the enemy is 500 or 600 yards from you, how many mares, tirelre or thirteen feet high, will there be between you and your enemy? Howerer little the rolling of the slup may be-(we will give the gallant oflicer the adrantage of supposing that lis low. freeboard will exceedingly nitigate the roll of the ship, which $I$ do not deny for a moment, prorided it be really low)-ret he can only fire at his eucny when he is at the top of the ware, and he cannot fire at that cnemy's water-line when warcs thirteen feet high are between him and the enemy; therefore one great adrantage of his artillery is lost to him when ho takes a low freeboard as the condition of a sen-going ship. And let me put the alternatire. Iro says, Well, I will not take a low freeboard for my sea-going ship; I will tako a high one for the sea-going ship; he at once departs from the principlo that he has adrocated so long aidl so persistently, that the great adrantage of a turret-ship consists in its lowness and in its smallness; for it must bo evident to crersbody who has erer considered these subjects for a moment, that when you begin to talk about the lowness of a ship, a rery low ship alone cnables you to hore a small ship; but the moment you deternine that your artillery shall be mounted at a considerable height abore the water, all the conditions of equilibrium, sen-going, and sea-worthiness demand that you should bare at once a high and, therefore, a largo ship. There comes in, therefore, at once an objection to which I lave nerer heard a satisfactory reply, to endearouring to make small turret-ships sea-going, cspecially when combined with speed; tho speed that you can obtain, and the weight that you carry in all ships must necessarily be antagonistic one to the other-that is to 825 , that you may turn with the greatest ease the weight that jou carry on a ship into specd; or vice versa, fou may turn that speed into weight by reducing the speed. Those two things are convertible. If, therefore, we are going to hare a swift ship on small dimensions, we must sacrifice something; we must cither sacrifice some portion of tho armour-plating or some portion of the armament, in order to obtain a power to drire the ship at the rate at which she is to go. The two things, the speed and the weight to be carried, are, cateris paribus, perfectly interchangeable. If, thercfore, you are going to ask us to construct small turct-ships with low freeboards, you deprive us of the artillers, or rather of the porer of placing that artillery in such a manner as to be really efficacious to use, and you deprire us of the power of obtaining great speed. Thoso difficultics are, to my mind, almost insurmountable, as to the possibility of perfecting a sea-going turret-ship with low freeburd and of small dimensions; but this does not affect the question the least in the world of a turret-ship properly designed of large dimensions and with a high freeboard. The question, then, between the turret-ship and the brondside-ship stands upon an entirely different ground. Now, I must say, as I said when I com. menced, $I$ do hope in what I say $I$ shall not give offence, but it is my firm conriction that the great opponent of the turret-ssstem, as applied to sea-going ships, sits in that chair. That may seem extremely odd to many - the greatest opponent to the turret-system as applied to a sca-going and a cruizing ship, is Captain Coles; and for this reason, that, in my judgment, he lias adrocated impossibilitics. He has refused to accept, as a principle of a good sca-going turret-ship that her guns should bo high out of the water. Ho has contended that the true principle of a sea-going turret-ship is to hare her guns low in the water. Now, $I$ stand here to adrocate that the true principle of a sea-going turret-ship is, that her guns should be high out of the water, and not that they should be low. I hare already shid that the true principle of a const defence, the true principle of a piece of siege artillery, the true principle of a ship built to contend, as the Auericans fonght their actions, in iulaud 
waters, is a Iow frecboard; but that the true principle of a turret-ship to contend with the wares of the sea, to be a cruizing ship on the ocean, to gire accommodation to her men, and to go into nction with a certainty of orercoming all her opponents, is in truth a gun high ont of tho water, and not lowness of freeboard. It is this particular point that is most interesting to we, and that has induced me to come here, and howerer imperfectly (as I know it must be, howerer much I may hare wearied evergbody here) I have endearoured to point out what I really think is the true philosophy of the turret-system, thero is no question of this-that wo enn do this much-we can mount rery heary guns in our turrets, we can carry thoso guns at a considerable height out of the rrater, re can, under certain circumstances, that will occur to crergbody, cnter into action with another ship with erery prospect of success prorided we are not restricted by small dimensions; but I do not think that eren that mucl prorcs, so entircly as I dare say somo of the adrocates of tho turret-system think it prores, that you should build nothing but turret-ships, or that turret-ships alone are sufficient to maintain a Navy like that of England in all the conflicts and all the dirersities of serrice that that Nary would have to go through. I do not think it can, but $I$ am perfectly willing to admit, and I desire to impress upon erergbody who hears me, that we are persuaded, and hare been persuaded for a long time, that the proper application of the turret-system to a sca-going eruising ship was the exact opposite of that its worthy inventor, its parent I may say, thinks it ought to be. I am sure anybody will understand how difficult, therefore, it las been ever to come to any understanding on the subject. I hare the strongest possible belief, founded, I think, on positions that cannot be shaken-that the high gun is essential to a turret-ship; a low gun cannot bo used effectirely in a sea-way-a low gun could only be fired, as I said before, when the ship is on the top of the sea, and eren then, between her and the enemy there may be wares so high-because the height of wares differs in half-a-mile it may be, sereral wares of one height and sereml of another - the ware will be between her and the object, and she will not be able to see the object or to strike it; whercas, if the gun were fifteen or twenty feet out of the water, you would look orer all those wares and see your object from first to last. When upon the deck of a ressel in a gale of wind, that deck being from fifteen to sixteen fect high, we hare all repeatedly seen a ressel within 300 jards of us, disappear, and hare seen nothing but his main topsail, but go to the masthead, and there you will nerer lose sight of him. Although that is an exaggeration of the position I wish to maintain, of the great adrantage of the height of the gun, it is an illustration of how necessary it is, in a sea-way, to hare a high freeboard and a high sight, all of which complicate the difficultics of constructing a ship in a rery remark: ablo manner. I only wish to refer to one other subject, and it is one which applies not only to what $I$ hare now been saying, but it applies to all turret-ships as a general rule. It is a subject of considerable dificulty, and I should not hare mentioned it if I had not secn it constantly and persistently orcrlooked. I am not bringing it forward as an absolute argument against the system, but only as one of the diffeulties of the system-as one of the things we hare to consider most carefully before we rush headlong into turret-ships. The turret inrented by Captain Coles is, as you know, armour-plated abore the deck. When it passes through the deck it ceases to be armour-plated, and the whole structure of the turret and the mechnism of the part on which it rerolres, is entirely unprotected by armour-plating on itself, though it is defended from anything that may hurt it by the ship's side- that is, by the armourplating on the ship's side, but it has no other defence. Now, unfortunately-I was going to say, thase confounded artillerists, but those terrible artillerists, as coon as crer we contrive to get an armour-plate and some backing of some giren strength or another, that resists, for the moment, all their efforts, do invent some horrible gun, and goclean through all our defences. It is rery annoying, no doubt, and rery proroking, but, howerer, thes will not stop for anything that we can say; we know they do go through 8 inches of armour-plating and a considerable number of other de. fences. We know that if a shot or a shell passes through $a$ ship's side in direct fre at 200 or 300 yards, that shot or shell striking upon the base, the unarmoured part, of the turret, where all the machinery is, would infallibly bring the whole of that turret to grief. Very little indeed would jamb the turet, and would prerent its 
rollers from turning round, and vert little indeed, in my opinion, would break through the unarmoured structure of the turret. That is not a fatal, not a rital objection, but it is an objection which people onght to weigh well before they put the whole of their guns into turets. Recollect, according to the most general scheme that we are acquainted with, two turrets are the most that you find in a ship; therefore it is possible-I do not say it is rery likely-but it is possible-that a couplo of shot from an enemy's broadside might disable both turets. Now, what is true of a turret-ship, is undoubtedly true of a broadside-ship; there is no question in the world, that shot and shell will find their way between the guns or abore the guns, or into the centre armour-plated battery of any ship, whether turet or brondside. What happens? A certain amount of loss of life in one case, a gun disabled perhaps, but your broadside with six or eight guns on one side, standts the blow, and goes on. You hare lost a gun, jou liaro had a gun dismounted, you hare-a gun's crew killed-rou cannot fight without these unplensant accidents oceurriug-but you are not utterly disabled; you hare still other guns and other men to come forrard and carry on the fight, and we know very well most of our actions hare been won when we hare becn half-beaten; but it is another consideration when your two turrets are jour whole offence and defenee, when you hare no other; - one of these shot, or two of theso shot passing through-and we know that they will pass through-may utterly disable or jamb the base of your turret and prerent its being used any more. As I said before, $I$ do not the least intend to use that as an argument against the turret system; I only say that it is not all on one side; that there is a grcat deal to be said on erery side of the subject-that it would not be prudent, that it would not be right, to embark the whole of the British Nary, or any considerable portion of it in turret-ships without further experience than we haro now lind; and I may say this-that so far from there being any disposition on the part of anybody in office or out of offiee, to $m 5$ lnowledge, to discourago the derelopment of the turret system, rery much the contrary is the case. Of course, like a member of tho Cabinet, I hare no business to retail Cabinet secrets; what passes, therefore, ovcl the may at Whitelall, and the discussions that take place on this subject, of course jou will not expect me to say anjthing at all about, but I think there are cridences which all here nust be well acquainted with, that the subject has not only been most carcfully considered, but has extremely warm adrocates in that council chamber to which I hare referred. Certain specehes which hare been made in Parliament and elserhere, certainly prore, $I$ think, at least that there is no unwill. inguess to consider the turret-ship in all its points aud in all its bearings. There is only one thing more I thint I may refer to, which I beliere was extremely well done by my friend Captain Scott. It is this. I did not hear, as I stid, the lecture the other day, but I know that there is a strong desire and a strong feeling to represent the imperfections of broadside slips, ns much as they possibly can be represented; and those who think a broadside ship is mrong in principle and wrong in practice, and the turret-ship is right, do rell in erery possible instance to adrocate their opinions fairly, and represent all the erils which belong to the broadside-ships; but what I was going to say is this, there are erery day in the broadsideship improrements made which add enormously to its offensive and defeusire character, and which take away many of the objections which are constantly urged against it. I am sure almost ererybody in this room is familiar with the talcnts, witl tho labour, with tho energs, with the unwearied zeal displayed by the Chief Construetor of the Nary in thoso productions which ho has turned out. I think ererybody will be aware that he improved the designs of the ships, improred the construction of the ships, and has been in a measure suecessful to an extent that perlaps it is lardly my prorince to say. Ho has slomn, in erery instance, the greatest possible deaire to improre our constructions, his success has been prodigious, and at this moment I speak, haring seen the opinions of many persons who hare come to this country purposely to inrestigate our iron-clad ships, who came here with a desire to find fault with our Ning, who came here thoroughly impressed with the beautiful descriptions that tho press sometimes gives of our performances, and believing that we were a pach of old women, and that we had no Nary, and were ready to be eaten up whenerer they thought proper to open their :retlis and smallow us. I hare 
the ducans of knowing, from letters that I lave seen, that one and all liaro left this cotutry with the impression that she is umiralled in her constructions at sca一 tunrivalled. I am also able to say this one rord-that the Assistant Secretary of a foreign Tary was ores here for some considerable time, and was asked at a diplomatic dinner the other day, what chance our neighbours would hare with us ? It is as well not to giro you that reply. But he was further asked, "What chance should we hare with the British Naryê" IIe answered in these words, "You " have got the finest line of defence on the waters in the rorld. Notling "can attack you, and your defence is perfect; but if you attempt to go to "sca, if you attempt to cross the occim, you would not be sir months, before you " would be swept away completely. You hare not got a single iron-clad sca-going "ship in your whole Nary;" and lie said more- "I went to Chatham the other " day, aud the most splendid spccimen of naral construction, I erer set my ejes on, " both in design and construction, was the "Hercules." " I need not tell fou MIr. Reed was the designer and the construetor of the 'Hercules.' I think all this is satisfaetory. I $\mathrm{nm}$ endearouring, by what I hare now said about broadside ships to point out that there is in broadside ships some rirtue-that they are not altogether, ats we hare sometimes lieard it said, absolutely out of date. The last construction in broadsides that we have put before the dimiralty, contains one or two features Captain Scott referred to, and which I think are of so much importance, as doing away with the objections generally made to broadside ships, that, at the risk of wearying you a little longer, I will state them. Of course everybody is aware that the great objection made to broadside ships is the want of power to train the gun upon all points of the compass. The great merit of the original idea that came across Cuptain Coles' brain, was that his turret could be pointed to every part of the compass. But he has been led astray by a will-0'-the-misp, giving up his first lore for something more specious and telling; he las given up that idea, and giren up that all round fire, which was so precious to me and to all otler consistent advocates of the turret sjstem, and he has now gone in to limiting his fire. I regret it extremely. There is in the "Captain" a want of all that round fire which distinguisled his carly plans; but I say that the broatsidlo gentlemen-those who are responsiblo for the construction of broadside ships-lare now adopted a plan by which such a ship will command crery point of the compass. In addition to those guns in the central battery-which las so often been denominated a box by way of depreciating it-not only have you guns in the box, but upon the upper deck, at a height, as Captain Scott has said, of something like 20 feet ont of water, giring jou, therefore, a tremendous conmand orer anybody alongside of you, we hare put two guns that will fire in a line with the keel and at a right angle to it. I see a gallant officer here-I am rery glad to see him here to night--iho has persistently adrocated that prinejple in rarious ways, and who, I hare no doubt, will be pleased at the derelopment we hare giren it; for if we hare not absolutely adopted all his recommendations, we hare profited rery much indeed by the lessons he has given us. We hare got that fire, that fore and aft fire, which is to him so extremely precions, and which he has been for a rery long time, not only a theoretical adrocate for giring, but has in the ships whose construction he has directed, adopted with the utmost ability. It is satisfactory to be able publicly to say that that officer, Captain Symonds, lias at all times, in many ways, contributed to us a rast amount of useful information-that he has put his models and his plans rery often, indeed, at our disposal, and giren us the benefit, and a very great benefit it is-of lis talents, and of the attention he has paid to that subject. There is but one thing morc, on the subject of broadsides. I am extremely sorry to hare detained you so long, but $I$ should not do justice to what $I$ have to say, if I did not rerert to this one point. The heary gun in a broadside can only be worked by mechanical means. When, in 1863 , the fact became evident that heary guns would really succed-(as ererybody here knows, there was considerable doubt for some time-gun after gun burst-and those who rere responsible for the adoption of ships to carry those guns were naturally staggered for a considerable time, and began to have a littlo doubt whether the big gun-tho rifled gun-would stand the severe shocks it was expoed to, and would cres" be a gun serred out to the Nary for ne: :)-but in 1863, my friend $\mathrm{Mr}$. Reed, with that prescient foresight 
about maval matters, which we have alnays known him to possess, und which is invaluable to a person in the ofticial capacity that ho loolds, became thoroughly conrinced that 12-ton guns would not only exist, but be mounted and worked in the broadside ships. At that time, I remember perfectly well, there came a number of naral officers to the council, that I hare spoken to you about, and there mas a great discussion, and the opinion given by all the naral offerers was, that only a 5-ton gun could be woiked upon a broadside ship. Now, it required some courage, and some knowledge of mechanism, and some confidence in his own resources, and in his own good sense, to induce Mr. Reed to kay, I will build a ship, and she shall curry 12-ton guns to work on the broadside. And now came the question, how we vere to work those guns. It was clear the plan of working a gun by handspikes would not do; for a long time it was persistently attempted to work these 12-ton guns on the broadside with tackles and handspikes, but there came upon the scene somebody who changed all that. I am happy to introduce Captain Scott as the person to whom we owe the change that has now taken place, in the opinion of all naval offecrs-a cliange, from the idea of its being absolutely impossiblo to work 12.ton guns on the broadside, to the couriction that it is the easiest thing in the world. - It is simply by the application of mechanism, and the mechanical foresight of Captain Scott, with an assiduity and a labour equal to the assiduity and labour which Captrin Coles has bestowed npon his turret-ship, that he has worked out a system by which the heariest guns are worked at sca, not only with as much facility, but with greater facility than the old GS-pounder on its gum-carriage. I am happy to say, that this is now a recognised fact. It required many trials and nuch persercrance on Captain Scott's part-it requircd a man whose temper was such, that lie would take no denial; that he would work on in spito of all diecouragement, and he has done so. The other day, I am liappy to say, I read a report from a Rear. Admiral and fire Naral Oflicers (a committec for monnting and working naval guns), who declared the difficulty was orer, and that lievry guns could be worked on tho broadside with perfect facility. 'The burden of what I liare to say is this-pointing out the dificulty of getting a sea-going slip as a turret-ship with a low frecboard, pointing out the incritable and insuperable objections to such a ship, and showing, as I think I have shown, the great facilities that now exist for mounting heary guns on the broadside principle, - I think I hare put the question on a fairer and more rational basis than it has yet stood upon. I think I hare shown-or, at least, I hopo I have shown, to this mectiug, that it is perfectly possible to have the rery best defence, and tho tery best siege artillery Jou can hare in low turret-ships; that it is possible to hare a sea-going turret-ship, prorided you will giro up the low freeboard, but that there is no renson whaterer for supposing that the lately designed broadside ship mounting heary guns upon its broadside by mechanical means shall not go into action with a turret-ship with equal chances, and that it is shill, nerve, resolution, whaterer you please, that would decido that action.

Captain TrLER: I think me must all thank Admiral Robinson for the very able way in which he has spolen upon this occasion. Captain Coles gave us, witli great ability, his sido of the question, and we have now heurd from tho highest authority the other side of tho question, in a manner with which, I think, we must all bo chamed-in consequence of tho impartiality and bindness with which ddmiral Robinson has spoken of ererybody concerned. Sitting opposite to this nodel, I have been watching it as Admiral Robinson spoke, and I hare been struck with it as a most excellent illustration of what he has been telling us. Comparing this broadside ressel with this turret-ship, as a sea-going ressel, it struck me at once that, in order to arrire from the one ressel to the other vessel [pointing], you hare to take a slice out of the former sessel on one side, and another slice out of the other side, and Jon pretty nearly cqualize the two scetions. As to the leight of the gun out of the water, Captain Coles has said, that he can make the turret-ship gun the samo height out of the water as the broadside-ship gun.

Captain Cores : I think you mill find that it is about the same.

Captain Truen: It appears to be about the same on the diagrani.

Admiral Rosisios: The rery principle we contend for is that the guns should be high, and not low. 
Captain TrLen: : At all erents, in this diagram it would appear the height is about the same; and as I said before, I do not see any reason why it should not be tho same. If it is not so, it might be made so; but then there is no doubt this disadrantage, that the gun being withdramn (and that is the principle of the turret-ship, that the gun is withdrawn) from the side of the ressel, it cannot certainly fire as directly upon the water as the broadside gun can.

Captain CoLEs : That gun can gire seren degrecs of depression, the sume as the broadside.

Captain Truer: It cannot possibly gire the samo as the broadside,

Captain CoLEs: Fes it can, it can be set to that angle of seren degrees.

Captain Truer : I do not know what the angle is; at all erents, if the gun cones a littlo within this point, it will fire upon the deck, that is obrious.

Captain Coles : No broadside can depress more than seren degrees.

The Crrmestax: You will hare an opportunity of noticing the point in reply:

Captain TrLen: At all erents it rould appenr, at first sight that the turret ressel would be a very uncomfortable ressel to go to sea in, as compared with the broadside vesscl, there scems to be so very little room to more about in it. 1 great part of the narrow space is taken up by the turrets, and the remainder is unarmoured. Now the colour of the model struck me with the idea that, possibly, if a resscl of that description went into action, the first thing her cnemies would endearour to do would be to set fire to the wooden unarmoured part; and $I$ apprehend, if the wooden unarmoured part were to bo set in a blaze, it would be quite impossible to inhabit this turret-ship.

Captain CoLEs : This is all iron.

Captain TrLer: If that is all iron, it clearly will not burn, and my objection falls to the ground. Then it seems to me, with these turrets, two, or three, or four, as the case may bc, it will be a rery a whward thing indecd if a gun burst in a turret. Guns are liable to burst, and if a gun bursts in a brodside ressel it does a certain amount of damage, more or less, and the ressel is not disabled. But if a gun bursts in a turret, it becomes a very awkward thing indeed; at all crents, that turret is disabled, and rou hare lost a half or one-third of your fighting power at once. Those are the principal objections that struch me, as I listened to this discussion; and I will not detain the meeting, not being a professional man, by any further remarks upon the subject.

Mr. BeLI GILLowdY : J[r. Chairman and Gentlemen, the subject under considera: tion is, as has already beeu stated, an all-important national one. It is a subject that has occupied my attention and study for about twelre ycars, and during that time I hare been in correspondence with the Admiralty. IIs name is rery mell known there; and I am rery happy to-night to meet the Controller of the ddmiralty for the first time.

The Cirsmusex : Will you hindly heep to the subject?

Mr. Gallowar: I beg to apologise. 'The subject-matter to-night iz, whether is the turret principle or the broadside principle most raluable for the protection of our country? It has been properly said, and here I perfectly agree with the lonourable gentleman, that each system has its ad santages for particular purposes. In plain terms, I say, as a working man, we can do almost anything with two kints of tools, but one is better adapted for the doing of work than tho other mas be. There is, howeres, a happs medium, and I contend for the medium thus. If we want, as I hare said in another place, a perfect figlting ship, we ehall be able best to attain that object by the combination of the two principles, namely, a fighting ship, part turret and part broadside. That can bo done, and it might be well-and liero I speak submissircly-if the ddmiralty would let but one of the old ships that has been sold, according to the statement made last nimht, at $\$ 216 s$. per ton, scarce the price of an old collier that is rorking betreen London and Neweastle-if but one of these ships could be placed at the disposal of Captain Coles and another party, who would gladly work with him, it would derelope practically the truth of what $I$ am now eaying. I submit, and I speak respectfully in this assembly, that therc is a consideration of the most paramount importance connected with our ships, besides the means of protection. 
What would bo the position of a ship of war during an engagement? I put it thus, what would be the position of a ship of war during an engagement from the cffect of shot striking thoso heary armoured plates, and then, by concussion and ribration, starting the rirets. I submit that your ship rould be nothing more or less than a coffin for erery soul on board, and I say that there exist means of preventing such a catastrophe in the application of the cellular principle of construction of armour, which ought to have been applied ere we had como to this state of things. Then, again, what would bo the position of our ships of mar, during the first engagement from the effect of any one shot-(and there would be new fighting tacties)-disabling the progress of that ship, by disabling the action of your screw propeller or rudder? What would be the position of the ship then? It would be simply a target to be shot at. And then, agaiu, is it not a strango anomaly that there are actually plans existing.-(Question). I know of no more rital question.

The Cusmaras: These are questions not raised in the paper. This is not discussing the paper.

Mr. GacLorir: Two minutes more, and I shall hare done. In all places and under all circumstances I will bot to order; but whatercr may be the opinion of gentlemen here with respect to questions, the vitality of erery question consists in the cffectireness of the Nary, upon mhich hang the destinies of our country; that is the all important question. With this one question I will close my remarks : How is it, and why is it that we hare a Nary which is deplored in high circles? Eren Sir John Pakington, in the Irouse, admitted that it was not in the state of effeiency in which it ought to be. Now if there be plans, why, in the name of common sense, iustice, and humanity, are those plans not applied to sare thousands of lises, and the honour of our country?

Captain IIEstromx, R.A. : I wish to say ono thing, which I do not think anybody has before mentioned in connection with the turret system, and that is, that you get a great amount of top purchase and rear purchase in a turret for your working gear. We know, now that shot and cartridges are bejond a man's handling (from their rery large size and weight), that mechanical arrangements for lifting them are necessary, and it is important to those who hare to seheme out the working of heary guns, to hare strong purchases both abore and abaft a gun, as rigid bearings for running in and out gear, as well as for shot-lifting. In tho turret system the whole arrangement of guns and turret revolving together, these bearings are always in the same relatire positions with the gun. I liare been engaged in sketehing out the interior workings of some turrets, and this has been one of $\mathrm{my}$ greatest considemtions, riz., to get all the bearings for working hear weights always in the same relative positions. It is not neecsary for a turret embrasure to be low, although a turret may be low, because on any scheme of nuzzle-piroting there is no difficulty in so arranging that erers degrec of clevation in that gun can allow the body of the gun to be below the embrasure; nnd although to raise the gum to positions of depression, it will hare to be a little above the lerel of the port, the gun will usually be lower in the turret than the horizontal line of the embrasure.

Captain CoLEs: I am sure it affords me the greatest pleasure to hare to reply after the rery courteous way in which I may say the turret sjsten has not beer attacked, for I think generilly, alnost the whole of the arguments used last night, on the main points are admitted. As regards MIr. Reed, no one is so znuch pleased as I am to find that whaterer lo may have been, and into that question $I$ mill not enter, lie is now a supporter of the turret system; and that he bay be considered after his speech of last night, to hare finally joined the "innovators," as he honoured us by calling us. His position, no doubt, precluded lim from any attack upon any of the main arguments addressed by me, to show the superior adrantages of the turret system orer the brondside, for heary ordnance. I will refer rery shortly to the incidental points touched on by Mr. Reed. But, first, let mo tell him, as regards my British sailors in the diagram, they are conrectly drawn, and measure 5 feet 8 inches in height, on a guarter of an inch scale, and that the illustration they afforded my argument, mas cqually fair at both ports. I anticipated such a remark from past experience, Mr. Reed liaring macle tho same remark with regard to that diagram of rolling in 1863 , which, by tho Admiral's re- 
port that I read last night, has only proved too truc. I made both set of men exactly the same size. One would really hare thought, from lis criticisms on the height, that he, as a ship-builder, was not aware that the deck on which the sailor stands, was lower than the port-sill. As for the plating below water, I hare not gone backwards in reducing that plating below water. Ihare shown that the low frec-board will not roll a redaced quantity of armour out of water, and thus cxposo the unprotected part. Therefore to hare added the additional quantity, would have been tho surest bungling, if I may so call it. It would have bcen to make the country pay for an extra quantity of elicatluing, to injure tine qualities of the slip. At the same time, I should add in explanation, that the "Captain" has three fect less beam than tho "Bellerophou;" and for that reason only requires somerhat less plating. As regards the comparatire cost of the "Bellerophon" and the "Captain;" I will not go further into the Dockjard mystery of the charge for plant; for if $\mathrm{IIr}$. Reed, with his official experience, thinks the mystery unfathomable, I am quite ready to put it down as one of those things which "no fellow can understand." At the same time, as the interest on contractors' plant must enter fuly into the cost of the "Captain," I really do not see that the figures I hare shown hare been erroneous. It was $\$ 130,495$, the cost of the "Bellerophon," (though the accounts are not made up, not complete, and the cost of tho "Captain," was $\$ 335,000$. I stated, as you may remember, in both cases, that the nccounts were not yet completed. As regards the statement, that the "Bellerophon" only had two guns:- mhat is stated in tho Report is that the "Bellerophon" only fired tro shot. Well, Mr. Reed states, and no doubt correctly, that she had but two guns, and fired one round from cach. She might, of course, hare fired the prescribed number of rounds from each of those guins, if it had been thought safe. Aclmiral Warden's Report says :- "We could "hare opened all the main decls ports, but judging by tho effect of opening only "fire, it would hare becu to hare washed the men array from the guns."

Mrr. ReED : Exeuso me, that is not the "Bellerophon."

Captain Coles : It was with the "Lord Clyde;" therefore, the "Bellerophon" had apparently a great advantage, in this little broadside diffeulty, in haring, at all erents, four-fifths of her ports, clearly closed against the water. As regards tho relatire power of stowing extra coal in the "Bellerophon" and "Captain," Mr. Reed cays it is, at least, cqual, or, if anytling, greater in the "Bellerophon," than in the "Captain." But, according to the plan of accommodation and battery of the two ships, it may be prored, if time would admit, that this could not be so. It could be stowed in the "Captain"-on tho deck below, between tho two turrets-without interfering with the accommodation neccsary for the complement of $400 \mathrm{men}$; or with the batters, or the trim of the ship, as it rould be in the centre of the ressel. Wherens, in the "Bellerophon," it could not bo stowed in the centre rithout blocking up her guns; nor at the ends, without interfering materially with the requisite accommodation for her complement of $556 \mathrm{men}$; or, with the trim of the ship; because you would hare to stow it cither before or abaft the battery. Having thus noticed those points to which $\mathrm{Mr}$. Reed seemed to attach importance, I must ald that on the general question between turrets and broalsides, they are comparatircly unimportant. dssume for the sake of argument, that the "Bellerophon" is the very best broadside ship that money or shill can produce, and that sho will at all times have an eflicient supply of water-tight cartridges, of what use would she be against a good turret-ship, if sho cannot open her ports with safety in a good strell? and if she is liable to hare her fighting crew disabled by the entry of onlr one 300-pound shell through any one of her ports, into her square box? Howerer, now that she is built, I trust she rill be as sucessful as her designer can possibly desire, Now, as to the "Wytern," which has been quoted as a turret-ship on this occasion in the Admiral's reports, I rery fully stated in my lecture the reason why she should not be considered a sea-going turret-ship. I said, as it is, tho " Wirem," mithout the requisite addition, has been used to disparage the farourable conclusions as to tho furret system arrired at by both Admirals and it is curious that the only remark Mr. Reel made in apparent or partial disparagement of that system was founded upon that rery "Wyrern," and upon the assumption of her being a fuir representa. tion of a sea-going turet-ship. I agre with ML. Reel, that it is not fail to quote 
from a report only that which is in onc's farour; and if I lant admitted the "Wrrern" to be a reasonably fair representation of a sca-going turet ship, I should of course hare quoted erery word of the report which related to her. As I do not so consider her, and as early as 1864 wrote to the Secretary of the Admiralty to that effect, I think I was entitled without nnfairness to read only such parts of the printed report as related to broadside ships, sdmitted to be good specimens of their respectiro classes, and to leare to others, if they thought it worth while to rest their defence of the broadside ressels, as Mr. Reed seemed inclined to do, upon the comparison with the "Wyrern." I think this also may answer Captain Scott upon that point. As regards the effects of a low frcebonrd upon rolling, Mr. Reed admits that up to $n$ certain height the lor freebourd has that effect. Thie only question between ns, therefore, is one of degree. In the suggested comparison I made of the two ressels, you will remember that at the first they both rolled 20 degrces, their guns being assumed to be the same height abore the water, and in that case the turret gun was not, and the broadsido gun was, in the water. I think that is clearly ahown. Then I assume the low free board would roll only 7 degrees to the broad side rolling 20 degrees. I assume that ; it is part of my argument that the low freeboard rolls less, which is also partly admitted. Mr. Reed would admit that this will be truo up to a certain height of freebourd. Here again tho question between us is one of degree. Time will not admit of my auswering evers point, but $I$ will try and answer $n$ few. Captain Scott gare us a rery interesting sketch of gun-carringes, and also of rolling and so on. With regard to the "Wrrern," I think that is already answered. With regard to the gun-carriages, he spoke of the cxercise at some of these trials being made with old earriages. Fo should have stated that the gun-carringes in the "Roral Sorereign" mere wooden carriages, and more or less defectire; and, what is more, they were not fitted with the applianees which I lad asked for, namely, the winches to run in and out. We heard the Controller of the Navy ably describo how necessary it was to hare mechanical applianees to run the gun in and out. For on this occasion, when these guns in the "Royal Sorereign" were fired, those winches were not applied, and they had the old carriages that had been condemned by Captain Osborn in 1864. But even then yon see we fired at the rate of one round in 1 minute and 23 seconds. Now, Captain Scott quoted some other firing, and admitted that they did not fire at a mark. The report of Captain Fey on this occasion goes on to say: "In both cases,"-the cases of the turret gun-a report upon the "Royal Sorereign," that is the double and single turret- " in both cases a small target was "fired at 1,000 jards distance, and good practice made." Now I contend that if Captain Scott's quotation was of a gum, not fred at a mark, but of quick firing, it rás no criterion at all, for the rery essence of the turret system is the power of taking aim, and the power of secing your enemy. It is a fact, and has always been knomr, that in broadside ports it is rery difficult to see the object, particularly when it is moring, and this difficulty accounts in a great degree for the slotmess of firing on that occasion, whew, as Admiml Warden says, it took him three-quarters of an hour to fire 15 rounds. The quick firing of the "Bellerophon's" gun”, which Captain Scott mentioned, I think is also answered by the consideration that they were not fired at a mark. One thing mentioned by Captain Scott was the rushing of the sca into the port, and he explained that you could shut the port up; but if youl shut the port up, as erery gunner knows, and you only hare the little lole for the rammer to go in and out of, we all know that it is a rery much slower process to load; and not only that, but during the whole of that time, the captain of the gun can see nothing whaterer. He has to wait until the port is up, to know if his enemy happens to be near. Ile has to search for his enemy; he lias to go right and left of the poit; and, as re know, it is very difficult to see the enemy at all; and jou are obliged to send an order from the upper deck, and then very often turn sour ship to find your enemy. Another thing was, that the gun-carringes upon which the experiments were made, referred to by Captain Scott, I believe were of iron, were thes not?

Captain Scorr: Certainly, As rou have questioned me, I mny'state I lare not quoted the "Roral Alfred's" firing, which was with iron carriages, but there was no incrcase of quicliness orer that from wooden carriages-none whaterer in firing. 
Captain COLEs : At all crents those carringes were of iron. I now hare the honour of answering the Controller of the Nary, and it is with great diffidence that $I$ do answer an Officer who has done so much for the Narr, and who holds such a distin. guished position in the Admiralty. I beliere that one of the first things the Controller mentioned was, that in smooth water he eonsidered the turret principle was the greatest reapon of offence and defenec-that is, as long as the ship is steady, and that is the pith of the whole thing. I have contended, and I do contend, that low freeboard is what will enable jou to keep the ship comparatirely more steady than by any other means. That is the present question. It is a matter of degree to what extent you carry it. Another point the Controller of the Nary mentioned was, that the turret gun, not being ligh out of the water, wares 13 feet high, interposec between the gunner and the enemy, would prerent his secing the enemy, or prerent a shot hitting the cueny ; but as the "Bellerophon's". gun is not 13 feet out of the nater, the same thing would occur mith her.

Admiral Robixson: I stated the figure. I stated the height of the gun being 5 feet in one case, and the interposing ware 13 fect. If you wish to draw a comparison with the "Bellerophon"-

The Cruirucas : Fou did not Icar that Captain Coles said, that tho "Captain's" guns, which is a ship approxinating in size to the "Bellerophon," are 11 feet 6 inches out of the water.

Admiral Roninson: I thought ho was quoting what I had said.

Captain CoLfs: I was quoting the height of the ware. In fact, I think I had not explained myself. Tho ware is 13 fect hingl, so that any broadside ship, with a gun less than 13 feet out of water (and $I$ do not think any broadside ships hare their guns 13 feet out of the water)-any ship with a gun less than 13 feet out of the water would hare such a ware interposed between the gun and the object. But with regard to a difference as to the height of the gun ont of the water; I think it may hare cseaped the Controller's memory at the moment, he scems to think that our grent difference of opinion was about the height out of the rrater of these turret-ships, but it will be found that $I$ hare proposed, and do propose, tesscls of all descriptions and heights out of water. For instance, you will sce here a high freeboard, and different ways of mounting turets hare been sent to the Admiraltr. IIere is a turret mounted on a pirot going down to the lower deck; here is a turret on a circular box, on purpose to give her a high freeboard. Here is a ship, the first sea-going ship drawn out by Mr. Barnaby, No. 4 ; she has a square box in the centre, on purpose to gire a high freeboard. That ship's gums are higher than most ships, they were 13 feet out of water. That ship was proposed by me, and drawn out in the Controller's office in 1863. The "Royal Sorereign's" guns are 12 feet out of water. The "Naughty Child"-a ressel sent in in 1863-her guns were 10 feet out of water. The turret-ship designed in 1863 I hare noticed. The "Captain" is 11 feet 6 inches out of water. So that it is a mere matter of degree how high you have your gun out of water, and, of course, your freeboard, it may be supposed, is gorerned by that. But it is not so in a turret-ship. You can hare a low freeboard and a gun a great height ont of the water, as much as 11 feet or eren more. You have only, as I hare explained, to slope the deck considerably, as you see there; I merely mise the turret a little, and get my gun ligher. Instead of that, if you wish to get a gun ligher out of water in a broadside ship, you lave to increase the height of your broadside ship, and to increase all that extra weight. I hare only to increase the lreight and the small weight of the cylinder of the turret. On this point, I think the Controller said re hare not been able to come to any decision in these turret-ships. But I hope I may be allowed to say thant, with all the rarious propositions which I hare sent in from time to time, the Controller had a griat many specimens before him, and it did not rest with mo whether a ship of that sort was built or not; I had only to gire my plans, and it rested with the Controller's department. I merely made suggestions. I did not prerent ships from being built, and therefore I cannot quite see that I hare been the stopper to the sen-going ships, when I see all these different classes proposed by me. But, again, how is it, if $I$ hare been the stopper to building sea-going ships, low is it that sea-going turret-ships, built at prirate yards, have crossed the Atlantic; when 
we hare not a sea-going ship in the Nary. Now, Gentlemen, a letter was put into my hand, which, if you will allow me, I will read, and I think it will be rery interesting. It is written to me bs an offeer of distinction in the Ierurian Narg :-

“ Captain Coles, R.N.

"Loudon, 1st May, 1867.

"Sir-As you are giring a lecture on turret-ships, perhaps you mould like to have " the following particulars of the turret-ship 'Huascar,'. which was built under my " direction for the Perwian Gorernment, by Messrs. Laird Brothers, and taken out "by me to Peru.

"In the report addressed by Commander Garcia, commanding officer of the Peru-

".rian ironclad frigate 'Inclependencia,' to the head department of the Nary, on his

"royage from Europe to tho Pacific, in contos with my slip the 'IIuascar' (earis-

" ing the Commodore's flag) and the wooden corrette 'America,' the following extract

" from that report is to be found inserted in the nerspaper El Comercio, dated the

" 24th of August, 1866:-

" "Or our arriral to the Pacific, the barometer" began to fall with adnirable " "rapidity, and as it was blowing hard from the $\mathrm{N} W$., we did not doubt we wers " "going to meet one of those heary gales so frequent in thoso latitudes. The " " weather, until then clondy and rainy, began to appear storny on the 30 th and " " 31st of Mray. This last das we met a rery stroug northern, which, changing " " suddenly into N.IV., became a violent and protracted stom, accompanied with " "hurricano squalls. ds it mas inpossible, under these circuinstances, to steer " ' the ship's course, mainly by the terrible broadside swell which was rising, we " " were lying to with fore stajsail and trysails, steaming under rcry casy steam, " ' to enable us to put the bows to the sea. Although the storm's strength dial " " not allom us to curry more sail than that which me carried, we were obliged to " " set the topsails under the close reef, as the ouly remedy to check the extra* " " ordinary rolling of the ship, which exceeded in many cascs $30^{\circ}$ on each " s side."

"Notwithstanding losing the comroy of the 'Independencia' and the 'America,' I "' had so much confidence in the 'IInasear' that I mado my direct course for Chiloe, "and arrired there at 9 A.3r. on 6tb June, the "America" the nert day at 11 1.M., "and the 'Independencia" at 2 r.x. the same day, that is, 29 hours after the " 'IIuscar.'

"I may add that the "Fuascar" is 1100 tons, carrying two 121.ton guns in her " turret, and two 40-pounders aft on deck, and that she was very buoyant and a good " sca-boat. 'The 'Independencia' is a broadside box ironelad, of upwards of 2,000 " tons and 550-horse power, not carrying any gun hearier than 150-pounders.

$$
\text { "I am, Sir, }
$$

"P.S.-We left Chiloe on the 11th June for Talparaiso, and met the same night " a screre gale, when we agnin parted company with the 'Indenendencia,' but " arrired at Talparaiso on the 15th, the 'Independencia' not arriving until the sext " day."

That was the first ironclad ship that went across the Atlantic, and that gentleman, I beliere, is present here to-night, and I hare no doubt he will tell you, if you wish it, with his own mouth, that that ressel was a beautiful little sea boat; her deck wes six fect out of the water. So much for the sea-going qualities of turret-ships. The Controller says that the turret-gun is unprotected between decks; that is that the turret is only protected by the ship's side. That is one of my rery great arguments in farour of low freeboard. Suppose, for instance, that a ship's side is ten feet out of water, and it is covered with six-inch iron, if you reduce that portion to fire feet, it is erident you can donble the iron on that portion which would make it one foot of iron. So that if that is the case in low freeboard, thint is another great reason why you should adopt it. And ngain, if the turret-guns are unpro- 
tected, are not the guns of a broadside-ship much more unprotected, where ron lare the rery much ligher side, and, as we finch, a rery much thinner side in proportion, with all thesc numerous port-holes for the entry of shell, and, I think, jou all know that the entry of one shell in such a casemated battery as the "Bellerophon" would be quite sufficiont to put that ship hors de combat; nt all orents for some time-shells with 12-pound charges. Another objection was that the all-round fire of the "Captain" laad been sacrificed. It has been saerifiecl to a certain point. That is, we can fire the 600-pounder within six degrees of the line of the kecl. Now; is there any other ship in the eerrice that conld fire the 300-pounder at the same angle? They may fire their smaller guns by poling them out of the port-holes in the bow, but they will not be able to fight those guns steaming against a head sea, whercas the gun in the turret-ship being well placed, can, when steaming that ship against a head sea, still be firing nearly right ahead. I think, gentlemen, nothing cau be more satisfactory, or more hind, than what the Controller has said. There is, homerer, one point more. It was mentioned that a gun bursting in a turret would do rery great damage, but I must remind you, that the gun or a shell bursting, or anything bursting in a turret, is just where it mould hare the adrantage orcr $n$ broadside-ship. If the gun bursts in $a$ broadside-ship it creates a panic on the whole of that deck, and nasy not only bill the crew of that gun, but the erew of the gun next to it; whereas a gun bursting. in a turret. is localised to that particular point, to that oue turet. Perhops if the gun burst here, you would lose the power of one turet of two guns, but if a gun burst on that deck most likely the whole deek would be put hors de combat, particularly with theso 40 -pound charges. In fact that is one of the great points that are pointed out as an adrantage in the turret by Captain Powell in his report of 1861. I will not troublo you by reading that report, as I think I read it last night, but it says that one of the great advantages is, that if $n$ shell burst in the turret, or a gun burst, it would be localised to that particular turret. There is jet one other point that I will refer to. The Controller said, and I was rery glad indeed to henr it, that he had always been a great adrocate of the turret, and is so norr, for special purposes. Well, Gentlemen, it has giren me the greatest pleasure, nothing could lare been more satisfactory, for what did I say last night? I think you will find that I particularly pointed out that, as a rule, special vessels must be built for special purposes where armotu' is inrolred, but that the turn-table and shield which combine to form $\mathrm{my}$ turrets, admit of war ships being constructed which can serre for more genernl purposes than the broadside principle admits of. "For instance, ressels capable of the defence of our shores," that is the rery first thing, I think, the Controller of the Nary was pleased to grant to the turret-systcm, "or colonies, fit for the close attack " of an enemy's strongholds, carrying the heariest cannon that we can manufacture, “ and yet capable of crossing the widest occan, can only to-day be found in existing "ressels with a very low freeboard and turrets." I think upon that point re may consider that we hare no longer the slightest difference of opinion. I da not know whether there are any other particular points which I may be called upon, or which it is necessary to answer, but I think I hare touched gencrally upon all. I can only conclude by kaying, that this lecture and discussion, howerer much trouble they may hare caused me, hare been an inmense pleasure to me, not only because I consider that, to a rery great extent, the turret principle is admitted to be right, but I hare found, and am happy to see, that there is such n great disposition and such a great cffort that our Fing should benefit by it. It only remaius with mo to thank you, and to thank the Controller, and all of those gentlemen who hare contributed to the information which I lare gained, nnd which it has been my purposo to gain in laying my views before others. I still think and feel, as I sar, that for special purposes you must hare different resscls. As I mentioned last night, those vessels with rery low freeboard, whose eails were left out, are not meant for sailing, they are only meant for steam-power, and with regard to the whole of those ressels, my opinions are rery much strengthened by what I hare heard. I hope, gentlemen, that we shall not only hear of other ressels crossing the Atlantic, but that we shall soon liare turretships to do the same.

A Visitor: I am requested by Capt. Salcedo, as he does not understand English 
very nell, to translate for him, and he will have much pleasure in answering any question put to him about the "Huascar."

The Chamsas: Can you say what is the thickness of the armonr-plating?

A Vistron: Four inches and a-half armour-plating.

The Cramsas: What was the size of the ressel f

Captain Coles : I can gire sou all the information.

The Charrss: : At this late hour, perhaps it is hardly necessary for une to add anything. I slould like to hare unade some remarks, but at this late loour it is not desirable. It nust be remembered that the condition of the turret and broadside question is tery different now to what it was when it was enunciated by Captain Coles, and I must say that $I^{-}$think the present position of the matter is rery much owing to the persistent and talented way in which he has prosecuted his work under rery great disadrantages. He has already stated to jou- that we lare not got a turret-ressel in his estimntion such as would afford us the infornation that we really require to enable us to come to anything like a satisfactory conclusion as to the relatire merits of the two systems, and I do think that the burden that has been laid upon the "Wyrem" is too great, and is not at all such as wonld warrant any comparison whaterer between her and "Bellerophon." She is a very small ship; jou cannot make any real comparison, unless the two ships are sinilar in size. It is quite out of the question. It is quite clear the main pinciple of the turret systen, that is, the idea that Capt. Coles hns, that a low freebonrd will produce an easy ressel, a ressel that would not roll much, is admitted by $\mathbf{M r}$. Reed rery justly. I quite endorse his opinion that it rould have that effect. I also endorse lis opinion that if the frecboard were high, in proportion as it were high, it would do away with the adrantage which had been originally contemplated by Captain Colee, and the ressel would be in that proportion uneasy. Therefore the statenent of the Admiral that if the ressels had had their guns a certain height in the turret-ship that they would hare had great adrantages orer the broadside ehips-Captain Scott did not quote correctly-I beg his pardon, he quoted correctly, but I do not think he interpreted it correctly, because tho latter clause of the quotation clearly implied that the Admiral was speaking of the height of tho gun, and not the height of the freeboard. Now as the principle of the turret system is to hare a low frceboard for the purpose of getting an easy ship, it nould hare been destroyed by haring a high one; therefore, if the gur is high, that is all that is really wanted. You have a ligh gun, a low freeboard, and you get an easy ship. Now, I believe, a combination of the two systems would make a far better one. I am quite sure that the old system of French ships was a rery wise system. It was discontinued in great mensure because of the necessity of haring more space on the decks for larger guns. Now you are introducing that which undoubtedly is 'due to Captain Coles, and that is the turn-table, and that practically is a long approach tomards his system, and certainly he is entitled to the full and undoubted credit of that. I do not think that you could hare fought the large guns mith adrantage, or mith safety if you did not use the turn-table. Therefore that is of rexy great importanec, and I do think the fact of his haring intro. duced the turret and the tum-table, has led rery much to a more early adoption of large guns into the Nary. I quite feel, too, that the discussion on the turet system will lead to what I beliere to be essential in easy ships, and that is, narrower shipo than we hare. With respect to the uneasiness and the difficulty of those ships firing their guns, Captain Scott says, it was a defect of the carriages, but why were the carriages so defectire? Because the sudden, the mpid, and extensire motions of the ships, required more than ordinary skill and care of mechanical conetruction. With respect to the construction of those carriages, I say, the rery failure of the carriages, while it obliges you to get a more effectire carriage, also onght to point out a defect in the ship, either in the storage amanrement, or construction, or form, I cannot say which. It is, no doubt, a rery comples question, and one not easily dealt with, but as attention does orercomo difficulties that ought to bo orercome, it is essential that it slould be orercome, and I do not beliere that there is any insuperable difficulty in orercoming it. There are adrantages in the turret system which I think are rery decided mith respect to the gun and to pointing of the gun,

voL, $\mathrm{XI}$. 
and I mu-t say until this discussion took place, I ras not axare it had so many adran. tages as it has. Of courso we are not prepared to sas, that it has perhape the extreme adrantages claimed for it by Captain Coles, or that the broadside system has the extreme disadrantages. Howerer, I accept, and I think we all agree to that, that there are specialties, aud jou must have particular ships for them. You cannot saj sou will hare all turrets, and jou cannot hare all broadsides. But what is really wanted is, that we shall all put our heads together and agree to work together, as wo hare a common object, a common end, a common interest, and each accepting opinions and ideas one from the other, borrowing not stealing, giring credit where creclit is duc, and honor where honor is due. I think jou will allow me to retum your thanks to Captaiu Coles for his very clever, and rery ingenious prineiple, and I an sure if he had not had a more than ordinary mechanical genius he could not hare orercome the dificulties that he has had to contend with; and he would not. hare brought it to the perfection he has. On the other land, wo muet gire credit to the Departments who are going in the direction of recognizing the principle dis. tinctly, and of frankly arowing the value of that principle, and are adopting it so far as they conceire consistent, and of course erery man in a position of trust and responsibility, must cxereise his own judgnent, ho must not accept another mun's judgment. He is responsible, and of course as he is responsible, he must exercise his own judgment in the matter. I hare much pleasure, Captain Coles, in returning jou the thanks of the meeting. 